\title{
PRZYSTOSOWANIE DO CHOROBY NOWOTWOROWEJ U PACJENTEK Z RAKIEM SZYJKI MACICY
}

\author{
ADAPTATION TO CANCER IN PATIENTS WITH CERVICAL CANCER \\ Dorota Rogala', Aleksandra Mazur ${ }^{1,2}$, Mariola Maślińska, ${ }^{1,2}$, Magdalena Krawczak ${ }^{3}$ \\ ${ }^{1}$ Katedra Onkologii, Radioterapii i Ginekologii Onkologicznej \\ Collegium Medicum im. Ludwika Rydygiera w Bydgoszczy, Uniwersytet Mikołaja Kopernika w Toruniu \\ ${ }^{2}$ Klinika Ginekologii Onkologicznej, Centrum Onkologii im. prof. Franciszka Łukaszczyka w Bydgoszczy \\ ${ }^{3}$ studentka, licencjat położnictwa, Collegium Medicum im. Ludwika Rydygiera w Bydgoszczy, Uniwersytet Mikołaja Kopernika w Toruniu
}

DOI: http://dx.doi.org/10.20883/pielpol.2016.6

\section{STRESZCZENIE}

Cel. Celem pracy była ocena związku między przystosowaniem psychicznym do choroby nowotworowej a poziomem poczucia własnej skuteczności u kobiet z rakiem szyjki macicy.

Materiał i metody. Badaniami objęto 30 kobiet $z$ nowotworem szyjki macicy po leczeniu chirurgicznym. Wykorzystano ankietę własnej konstrukcji, Skalę Uogólnionej Własnej Skuteczności GSES i Skalę Przystosowania Psychicznego do Choroby Nowotworowej - MINI-MAC. Analizowano zależność między wyborem strategii do walki z chorobą a poziomem własnej skuteczności w zależności od zmiennych socjodemograficznych. W obliczeniach statystycznych wykorzystano testy: ANOVA, ANOVA rang Kruskala-Wallisa, MANOVA, U Manna-Whitneya, współczynnik korelacji r Pearsona. Jako poziom istotności przyjęto $p \leqslant 0,10$.

Wyniki. 1. Kobiety z rakiem szyjki macicy wybierają konstruktywne strategie walki z chorobą: ducha walki i pozytywnego przewartościowania. Wiek, wykształcenie, miejsce zamieszkania nie różnicowały pacjentek w wyborze strategii. Gorsza sytuacja materialna korelowała z większą skłonnością do stosowania strategii destrukcyjnych. 2. Spośród zmiennych socjodemograficznych na wzrost poziomu własnej skuteczności miały wpływ jedynie lepsze warunki materialne. 3 . Kobiety z wyższym poziomem własnej skuteczności częściej wybierały strategie ducha walki i pozytywnego przewartościowania.

Wnioski. 1. Kobiety z nowotworem narządów rodnych dobrze przystosowują się do choroby. 2. Wyższy poziom własnej skuteczności sprzyja wyborowi konstruktywnych strategii.

SŁOWA KLUCZOWE: GSES, MINI-MAC, rak szyjki macicy.

\section{Wprowadzenie}

Nowotwór szyjki macicy jest jednym z częściej występujących nowotworów u kobiet. Choroba nowotworowa często związana jest z higieną życia kobiety. Właściwy tryb życia może zmniejszyć ryzyko zachorowania na ten nowotwór. Kobiety, które rozpoczęły życie seksualne w młodym wieku, miały wielu partnerów seksualnych, palą papierosy, ich dieta jest uboga w warzywa i owo-

\section{ABSTRACT}

Aim. The aim of this study was to assess the association between mental adaptation to cancer and the level of self-efficacy in women with cervical cancer.

Material and methods. The study involved 30 women with cervical cancer after the surgical treatment. We used a questionnaire of our own design, Generalized Self Efficacy Scale - the GSES, and The Scale of Mental Adjustment to Cancer Diseases - MINI-MAC. We analyzed the relationship between the choice of strategies to fight with the disease and the level of self-efficacy, depending on sociodemographic variables. In the calculation of statistical tests were used: ANOVA, ANOVA rank Kruskal-Wallis, MANOVA, Mann-Whitney U, Pearson's correlation coefficient $r$. As the level of significance there was $p \leqslant 0,10$.

Results. 1. Women with cervical cancer after surgery chose constructive strategies to combat the disease: fighting spirit and a positive revaluation. Age, education, place of residence did not differentiate patients in choosing strategies. A worse financial situation was correlated with a greater propensity for using destructive strategies. 2. Only better material conditions had an influence on increasing the level of self-efficacy among the sociodemographic variables. 3. Women with higher levels of self-efficacy often chose a fighting spirit strategy and a positive revaluation.

Conclusions. 1. Women with cancer of the reproductive organs are adapting well to the disease. 2. Higher levels of self-efficacy favor the selection of constructive strategies.

KEYWORDS: GSES, MINI-MAC, cervical cancer.

ce oraz przez wiele lat stosują doustne środki antykoncepcyjne, narażone są w większym stopniu na zachorowanie na raka szyjki macicy. Objawy pojawiające się w początkowej fazie choroby nie są charakterystyczne, dlatego tak ważne jest uczestnictwo w programach profilaktycznych. Obejmują one kobiety w przedziale wiekowym 25-59, które w przeciągu ostatnich 3 lat nie miały przeprowadzonego badania cytologicznego. Pomimo tych działań nadal wskaźniki zachorowań na raka 
szyjki macicy w Polsce są wyższe o około $15 \%$ w stosunku do średniej UE, a umieralność jest nawet o 70\% wyższa niż przeciętna dla krajów europejskich [1].

Przystosowanie do choroby nowotworowej to problem radzenia sobie $z$ samą chorobą i jej konsekwencjami, a w dłuższej perspektywie - konieczność poradzenia sobie z szeroko pojętymi zmianami w jakości życia. Psycholodzy wyróżniają dwa ogólne style, jakie prezentują pacjenci w walce z chorobą: styl konstruktywny, obejmujący strategie ducha walki i pozytywnego przewartościowania, oraz styl destrukcyjny, obejmujący zaabsorbowanie lękowe i bezradność - beznadziejność. Duch walki skłania chorych do traktowania choroby jako osobistego wyzwania i podejmowania działań zwalczających chorobę. Pozytywne przewartościowanie to takie przeorganizowanie problemu swojej choroby, aby przy pełnej świadomości jej powagi znaleźć nadzieję i zadowolenie z już przeżytych lat. Zaabsorbowanie lękowe wyraża niepokój spowodowany chorobą, postrzeganą głównie jako zagrożenie wywołujące strach, nad którym nie można zapanować. Bezradność - beznadziejność świadczy o poczuciu bezsilności, zagubienia, o biernym poddaniu się chorobie [2]. Wyniki badań dowodzą, że lepsze rokowania, biorąc pod uwagę długość przeżycia, brak nawrotów choroby i lepszą jakość życia, wiążą się z wyborem aktywnych strategii [3]. Ocena preferowanych strategii jest przydatna na każdym etapie leczenia i rehabilitacji.

Albert Bandura w 1977 r. opracował teorię modyfikacji zachowań ludzkich i wprowadził pojęcie poczucia własnej skuteczności. Wskazał, że samoskuteczność wpływa na motywację do działania i poprawia końcowe osiągnięcia jednostki [4]. Poczucie własnej skuteczności pozwala człowiekowi na odrzucenie lub zaakceptowanie danej sytuacji zależnie od przewidywanych jej skutków. W związku z pojęciem samoskuteczności rodzi się w człowieku poczucie kompetencji, która wyznacza zaangażowanie i dążenie do osiągnięcia sukcesu. Pozwala to jednostce na właściwe wykorzystanie posiadanych zasobów i przygotowanie konkretnego planu działania [5]. Badania potwierdzają, że im bardziej człowiek wierzy we własną skuteczność, tym wyższe cele sobie stawia i silniej angażuje się w zamierzone zachowania zdrowotne, nawet jeśli ponosi porażki. Częściej też wybiera strategie aktywnej walki z chorobą [3].

\section{Cel pracy}

Celem podjętych badań było wykazanie korelacji pomiędzy przystosowaniem psychicznym do choroby nowotworowej a poziomem poczucia własnej skuteczności u kobiet z rakiem szyjki macicy.

\section{Materiał i metody}

\section{Pacjenci}

Do badań zakwalifikowano 47 kobiet z nowotworem szyjki macicy po leczeniu chirurgicznym w Oddziale Klinicznym Ginekologii Onkologicznej Centrum Onkologii im. prof. Franciszka Łukaszczyka w Bydgoszczy. Ostatecznie badaniami objęto 30 kobiet, gdyż 15 kobiet odmówiło udziału w badaniu, 2 zrezygnowały z uczestnictwa w trakcie wypełniania ankiet. Grupa ankietowanych była zróżnicowana pod względem wieku, miejsca zamieszkania, wykształcenia, stanu cywilnego oraz warunków materialnych.

Wiek badanych mieścił się $\mathrm{w}$ przedziale 32-75 lat (średnia 55,4 roku). Wśród badanych najliczniejszą grupę stanowiły kobiety w wieku 50-59 lat (46,7\%), dalej 60-69 lat $(20 \%), 40-49$ lat $(13,3 \%), 32-39$ lat (10\%), 70 lat + (10\%). W dużych miastach mieszkało 11 osób (36,7\%), małych - 10 (33,3\%), na wsi - 9 (30\%). Spośród ankietowanych najwięcej miało wykształcenie średnie - 12 (40\%), dalej zawodowe - 7 (23,3\%), wyższe - 6 (20\%), podstawowe - 5 (16,7\%). Najliczniejszą grupę stanowiły mężatki - 18 (60\%), kolejno kobiety samotne - 10 (33,3\%) i będące w związku partnerskim - 2 (6,7\%). Warunki materialne jako dobre oceniło 15 kobiet (50\%), przeciętne 9 (30\%), bardzo dobre - 4 (13,3\%), złe $-2(6,7 \%)$.

\section{Metody}

W badaniu wykorzystano: kwestionariusz ankiety opisujący grupę kobiet pod względem socjodemograficznym i standaryzowane narzędzia: Skalę Przystosowania Psychicznego do Choroby Nowotworowej Watsona i wsp. z 1988 r. (polska adaptacja Juczyński, 1997 r. - współczynniki a Cronbacha dla poszczególnych strategii 0,87-0,92) oraz Skalę Uogólnionej Własnej Skuteczności Schwarzera i Jerusalema z 1992 r. (polska adaptacja Juczyński, 1998 r. - współczynnik a Cronbacha 0,85).

Skala Przystosowania Psychicznego do Choroby Nowotworowej - MINI-MAC (ang. Mental Adjustment to Cancer) - składa się z 29 stwierdzeń i mierzy cztery strategie radzenia sobie $z$ chorobą: dwie konstruktywne - duch walki i pozytywne przewartościowanie, oraz dwie destrukcyjne - zaabsorbowanie lękowe i bezradność - beznadziejność. Postawa aktywna charakteryzuje się ogólną mobilizacją i podjęciem walki o własne zdrowie, życie. Pasywna postawa przejawia się lękiem i ogólną rezygnacją pacjenta. Zakres możliwych wyników mieści się w granicach 7-28 pkt. Ogólny wskaźnik, po przekształceniu na jednostki standaryzowane, podlega interpretacji stosownie do właściwości charakteryzujących skalę stenową. Wyniki w granicach 
1-4 stena (10-24 pkt.) uznaje się za wyniki niskie, zaś w granicach 7-10 stena (30-40 pkt.) - za wysokie. Wyniki w granicach 5 i 6 stena (25-29 pkt.) rozpatruje się jako przeciętne. Im wyższy wynik, tym większe nasilenie zachowań charakterystycznych dla danego sposobu zmagania się z chorobą nowotworową [3].

Skala Uogólnionej Własnej Skuteczności - GSES (ang. Generalized Self-Efficacy Scale) - składa się z 10 pytań z możliwością udzielenia odpowiedzi w granicach od 1 do 4 pkt. Suma wszystkich punktów mieści się w przedziale od 10 do 40 pkt. Ogólny wskaźnik przekształca się na jednostki standaryzowane, interpretowane wg skali stenowej. Wyniki w granicach 1-4 stena (10-24 pkt.) to wyniki niskie, 5 i 6 stena (25-29 pkt.) przeciętne, 7-10 stena (30-40 pkt.) - wysokie. Im większy wskaźnik, tym wyższy poziom poczucia własnej skuteczności, co przekłada się na większą wiarę w siebie i umiejętności poradzenia sobie w trudnej sytuacji [3].

W obliczeniach statystycznych wykorzystano jednoczynnikową analizę wariancji (ANOVA), jednoczynnikową wielowymiarową analizę wariancji (MANOVA), test ANOVA rang Kruskala-Wallisa, test U Manna-Whitneya, współczynnik korelacji $r$ Pearsona. Jako poziom istotności przyjęto $p \leqslant 0,10$.

\section{Wyniki}

W pierwszym etapie badań analizowano, jakie strategie walki z chorobą wybierają kobiety z rakiem szyjki macicy. W grupie pacjentek przeważały strategie konstruktywne: ducha walki $(\mathrm{M}=22,63, \mathrm{SD}=2,88)$ i pozytywnego przewartościowania ( $\mathrm{M}=21,10, \mathrm{SD}=2,64)$. Po standaryzacji wyniki dla strategii konstruktywnych mają wartość 6 stena, co odpowiada przeciętnym wynikom uzyskiwanym przez populację, na której utworzono polskie normy. Strategie destrukcyjne: zaabsorbowanie lękowe $(\mathrm{M}=16,07$, $S D=4,42)$ oraz bezradność - beznadziejność $(M=12,63$, $\mathrm{SD}=3,76)$ w odniesieniu do polskich norm mają wartość 4 stena, co daje wynik poniżej wartości przeciętnych.

Do pomiaru związków pomiędzy wiekiem pacjentek i strategiami przystosowania do choroby wyliczono współczynniki korelacji liniowej r Pearsona.

Tabela 1. Wiek a strategie przystosowania do choroby Table 1. Age and adaptation strategies to the disease

\begin{tabular}{cc}
\hline Rodzaj strategii/Type strategies & Wiek/Age \\
\hline zaabsorbowanie lękowe/preoccupation with anxiety & 0,10 \\
duch walki/fighting spirit & 0,08 \\
bezradność - beznadziejność/ & 0,22 \\
helplessness - hopelessness & 0,22 \\
\hline pozytywne przewartościowanie/positive revaluation & \\
\hline
\end{tabular}

$0 \leqslant r<0,3-$ korelacja słaba/poor corelation

Źródło: opracowanie własne

Source: author's own analysis
Żaden z wyliczonych współczynników korelacji r Pearsona nie przekroczył poziomu istotności statystycznej wiek pacjentek nie jest związany ze stosowaniem określonej strategii.

Do sprawdzenia, czy pomiędzy miejscem zamieszkania i stosowanymi strategiami radzenia sobie $z$ chorobą występuje zależność, przeprowadzono wielowymiarową analizę wariancji MANOVA. Wyniki testu są nieistotne statystycznie, $\lambda(8,48)=1,28 ; p=0,28$. Miejsce zamieszkania nie wpływa na stosowane strategie radzenia sobie $z$ chorobą.

Poniżej przedstawiono wyniki analiz związku pomiędzy wykształceniem (test ANOVA rang Kruskala-Wallisa), stanem cywilnym (test U Manna-Whitneya) i sytuacją materialną (test ANOVA rang Kruskala-Wallisa) a wyborem określonej strategii. Do celów analizy zmienną „stan cywilny” przekodowano do postaci dwukategorialnej: 1. osoba w związku partnerskim lub małżeńskim, 2. osoba samotna.

Tabela 2. Strategie radzenia sobie z chorobą w zależności od wykształcenia (p1), stanu cywilnego (p2), sytuacji materialnej (p3)

Table 2. Strategies for coping with the disease, depending on education (p1), marital status (p2), financial situation (p3)

\begin{tabular}{ccccc}
\hline $\begin{array}{c}\text { Strategie radzenia sobie z choroba// } \\
\text { Strategies for coping with the disease }\end{array}$ & $\mathrm{N}$ & $\mathrm{p}_{1}$ & $\mathrm{p}_{2}$ & $\mathrm{p}_{3}$ \\
\hline $\begin{array}{c}\text { zaabsorbowanie leqkowe/preoccupation } \\
\text { with anxiety }\end{array}$ & 30 & 0,13 & 0,91 & $0,10^{*}$ \\
$\begin{array}{c}\text { duch walki/fighting spirit } \\
\begin{array}{c}\text { bezradność - beznadziejność/helples- } \\
\text { sness - hopelessness }\end{array}\end{array}$ & 30 & 0,77 & 0,74 & 0,33 \\
$\begin{array}{c}\text { pozytywne przewartościowanie/positi- } \\
\text { ve revaluation }\end{array}$ & 30 & 0,92 & $0,08^{*}$ & 0,36 \\
\hline
\end{tabular}

${ }^{*} p \leqslant 0,10$

Źródło: opracowanie własne

Source: author's own analysis

Przeprowadzona analiza statystyczna wykazała, że: 1. wykształcenie pacjentek nie jest związane z żadną strategią radzenia sobie z chorobą; 2 . kobiety żyjące w związkach osiągają przeciętnie wyższe wyniki w stosowaniu strategii bezradności - beznadziejności oraz pozytywnego przewartościowania niż kobiety samotne; 3. osoby o złej i przeciętnej sytuacji finansowej przejawiają wyższą skłonność do stosowania strategii destrukcyjnych.

Drugi etap badań obejmował ocenę poziomu własnej skuteczności - GSES - u kobiet z nowotworem szyjki macicy. Średni wynik mierzony w skali GSES w badanej próbie wyniósł 30,83 (SD = 4,86), co w przeliczeniu na jednostki stenowe odpowiada wartości 7 sten, uznawanej za wartości wysokie. Świadczy to o wysokiej samoocenie własnej skuteczności przez badane pacjentki. 
Dla ustalenia zależności pomiędzy wiekiem i poczuciem własnej skuteczności wyliczono współczynnik korelacji r Pearsona. Wartość współczynnika r = - 0,24 oznacza korelację słabą i jest nieistotna statystycznie $(p=0,20)$.

Poniżej przedstawiono wyniki analiz związku pomiędzy pozostałymi zmiennymi: miejscem zamieszkania (test ANOVA), wykształceniem, sytuacją materialną (test ANOVA rang Kruskala-Wallisa) i stanem cywilnym (test U Manna-Whitneya) a poziomem własnej skuteczności. Do celów analizy zmienną „stan cywilny” przekodowano do postaci dwukategorialnej: 1. osoba w związku partnerskim lub małżeńskim, 2. osoba samotna.

Tabela 3. Poczucie własnej skuteczności a zmienne socjodemograficzne Table 3. Self-efficacy and sociodemographic variables

\begin{tabular}{cc}
\hline $\begin{array}{c}\text { Zmienne socjodemograficzne/ } \\
\text { Sociodemographic variables }\end{array}$ & $\begin{array}{c}\text { Poczucie własnej sku- } \\
\text { teczności/Self-efficacy }\end{array}$ \\
\hline wykształcenie/education & 0,24 \\
miejsce zamieszkania/place of residence & 0,45 \\
sytuacja materialna/financial situation & $0,07^{*}$ \\
stan cywilny/marital status & 0,93 \\
\hline
\end{tabular}

${ }^{*} p \leqslant 0,10$

Źródło: opracowanie własne

Source: author's own analysis

Wyniki wskazują, że wraz ze wzrostem statusu materialnego pacjentek wzrasta ich poczucie skuteczności $(p<0,10)$. Pozostałe zmienne demograficzne nie miały wpływu na wybór określonej strategii.

Ostatni etap badań miał na celu sprawdzenie, czy na wybór poszczególnych strategii przystosowania do choroby ma wpływ poziom poczucia własnej skuteczności (współczynniki korelacji r Pearsona). Wyniki przedstawia tabela 4.

Tabela 4. Strategie przystosowania do choroby a poczucie własnej skuteczności

Table 4. Strategies for adaptation to the disease and self-efficacy

\begin{tabular}{cc}
\hline $\begin{array}{c}\text { Strategie radzenia sobie z choroba// } \\
\text { Strategies for coping with the disease }\end{array}$ & $\begin{array}{c}\text { Poczucie własnej } \\
\text { skuteczności/Self- } \\
\text {-efficacy }\end{array}$ \\
\hline $\begin{array}{c}\text { zaabsorbowanie lękowe/preoccupation with } \\
\text { anxiety }\end{array}$ & $-0,63$ \\
\hline $\begin{array}{c}\text { duch walki/fighting spirit } \\
\text { bezradność - beznadziejność/ } \\
\text { helplessness - hopelessness } \\
\text { pozytywne przewartościowanie/positive } \\
\text { revaluation }\end{array}$ & 0,49 \\
\hline
\end{tabular}

$0 \leqslant r<0,3-$ korelacja słaba/poor corelation

Źródło: opracowanie własne

Source: author's own analysis

Wyniki analizy wskazują na to, że poczucie własnej skuteczności jest powiązane z wszystkimi strategiami radzenia sobie z chorobą. W przypadku strategii destrukcyjnych kierunek korelacji jest ujemny, a siła zależności - wysoka. Oznacza to, ze wraz ze wzrostem poczucia własnej skuteczności spada tendencja do stosowania strategii zaabsorbowania lękowego oraz bezradności - beznadziejności. W przypadku strategii konstruktywnych siła korelacji jest umiarkowana, a kierunek zależności - dodatni. Wraz ze wzrostem poczucia własnej skuteczności pacjentki są bardziej skłonne do korzystania ze strategii ducha walki i pozytywnego przewartościowania.

\section{Dyskusja}

W grupie badanych pacjentek z nowotworem szyjki macicy przeważały strategie konstruktywne: duch walki i pozytywne przewartościowanie. Wiek, wykształcenie, miejsce zamieszkania nie różnicowały pacjentek w wyborze strategii. Kobiety żyjące w związkach osiągały przeciętnie wyższe wyniki w stosowaniu strategii bezradność - beznadziejność oraz pozytywne przewartościowanie niż kobiety samotne. Gorsza sytuacja materialna korelowała z większą skłonnością do stosowania strategii destrukcyjnych.

Juczyński w próbie normalizacyjnej kwestionariusza MINI-MAC na 266 pacjentach z nowotworami narządu rodnego, piersi, prostaty, żołądka, jelit, trzustki i krtani wskazuje, że częściej mężczyźni korzystają ze strategii destrukcyjnych niż kobiety. Ponadto w nowotworach narządów rodnych i prostaty przeważały strategie ducha walki i pozytywnego przewartościowania, a w nowotworach trzustki i żołądka - zaabsorbowania lękowego i bezradności - beznadziejności. Ogólnie w nowotworach dietozależnych dominowały strategie destrukcyjne, a w hormonozależnych - konstruktywne [3]. W dwóch oddzielnych badaniach (Michałowskiej-Wieczorek oraz Szczepańskiej-Gierachy i wsp.) u kobiet z nowotworami narządów rodnych i piersi również przeważały strategie konstruktywne [6, 7]. Odmienne wyniki uzyskali Malicka i wsp. Współczynnik dla aktywnych strategii dla kobiet $z$ nowotworami narządu rodnego był niski $(0,006)$, a dla strategii destrukcyjnych - znacznie wyższy $(0,141)$. Porównując dwie grupy pacjentek z nowotworami kobiecymi, autorzy wskazali na częstsze korzystanie ze strategii konstruktywnych przez chore na raka sutka niż narządu rodnego [2]. Kozak, badając pacjentów $z$ rakiem narządu rodnego, prostaty, trzustki i jelita grubego, wskazała, że pacjentki chore onkologicznie na nowotwory kobiece najczęściej spośród wszystkich grup pacjentów wybierały strategie konstruktywne. Im bardziej pacjentki akceptowały swoją chorobę, tym większe było nasilenie strategii ducha walki, a mniejsze - strategii destrukcyjnych. Największe nasilenie zaabsorbowania lękowego i bezradności - beznadziejności 
przejawili mężczyźni chorzy na raka prostaty. Ponadto inaczej niż w prezentowanych badaniach starszy wiek korelował z pozytywnym przewartościowaniem [8]. W innych wskazuje się, że wybór konstruktywnych strategii ma wpływ na większą aktywność samych pacjentów, lepsze dla nich rokowania i może ulegać zmianom adaptacyjnym w miarę trwania choroby [9].

W badanej grupie pacjentek z rakiem szyjki macicy poziom GSES wyniósł 30,83, co stanowi wynik wyższy niż przeciętna dla populacji polskiej. Nie wykazuje się zależności poziomu poczucia własnej skuteczności od zmiennych demograficznych. Jedynie lepszy status materialny korelował z wyższym GSES.

W próbie normalizacyjnej kwestionariusza do pomiaru GSES Juczyński wskazuje dla polskiej populacji wynik 27,32, w tym dla zdrowych kobiet - 27,13. W badaniach na różnych grupach klinicznych najwyższy wskaźnik miały kobiety po mastektomii - 30,07, i z rozpoznaniem migreny - 28,57, najniższy - 26,12 - leczone z powodu menopauzy. W badaniach Mariańczyk, Steuden kobiety po 45 . roku życia poddające się badaniom profilaktycznym w kierunku raka szyjki macicy miały wyższy poziom GSES niż kobiety młodsze [10]. W badaniach Majdy, Józefowskiej nad chorymi na POCHP poziom GSES obniżał się z wiekiem; osoby z wykształceniem średnim, mieszkające w dużych miastach miały GSES na wyższym poziomie [11]. Brak związku między wykształceniem a GSES stwierdziła Gapińska u pacjentów po zabiegu wyłonienia stomii jelitowej [12].

Wyniki badań pokazały, że istnieje zależność między wyborem strategii przystosowania psychicznego do choroby nowotworowej a poziomem poczucia własnej skuteczności. Wraz ze wzrostem poczucia własnej skuteczności rośnie tendencja do kierowania się strategiami konstruktywnymi, a niższy poziom GSES sprzyja wyborowi strategii destrukcyjnych. Podobne wyniki uzyskała Paul-Kańska [13].

Pacjenci, którzy są aktywni wobec choroby, realniej oceniają swoje możliwości, chcą o chorobie wiedzieć jak najwięcej, poszukują dostępnego wsparcia, nie rezygnują z dotychczasowej aktywności w wypełnianiu ról społecznych [14]. Dopiero jednak zestawienie pozytywnych strategii psychicznego przystosowania do choroby nowotworowej z przekonaniem pacjenta o swoich możliwościach i skuteczności daje szansę na osiągnięcie sukcesów w walce z chorobą.

\section{Wnioski}

1. Kobiety z nowotworem narządów rodnych dobrze przystosowują się do choroby.

2. Wyższy poziom własnej skuteczności sprzyja wyborowi konstruktywnych strategii.
3. Ocena wyboru strategii walki z chorobą oraz poziomu wiary we własne możliwości może być pomocna w dostosowaniu sposobu leczenia i rehabilitacji do danego pacjenta.

\section{Piśmiennictwo}

1. Krajowy Rejestr Nowotworów, www.onkologia.org.pl (data dostępu: 10.10.2015).

2. Malicka I, Szczepańska J, Anioł K, Rymaszewska J, Woźniewski M. Zaburzenia nastroju i strategie przystosowania do choroby u kobiet leczonych operacyjnie z powodu nowotworu piersi i narządów rodnych. Współcz Onkol. 2009; 13, 1: 41-46.

3. Juczyński Z. Narzędzia pomiaru w promocji i psychologii zdrowia. Warszawa: Pracownia Testów Psychologicznych PTP; 2001.

4. Bandura A. Self-efficacy. Toward a unifying theory of behavioral change. Psychol Rev. 1977; 84: 191-215.

5. Juczyński Z. Poczucie własnej skuteczności - teoria i pomiar. Folia Psychologica. 2000; 4: 11-24.

6. Michałowska-Wieczorek I. Rola wsparcia w zmaganiu się z chorobą nowotworową. Psychoonkologia. 2006; 10, 2: 51-56.

7. Szczepańska-Gieracha J, Malicka I, Rymaszewska J, Woźniewski M. Przystosowanie psychologiczne kobiet bezpośrednio po operacji onkologicznej i po zakończeniu leczenia. Współcz Onkol. 2010; 14, 6: 403-410.

8. Kozak G. Zróżnicowanie strategii radzenia sobie z nowotworem chorych w przebiegu wybranych nowotworów złośliwych. Anest Ratow. 2012; 6: 162-170.

9. Payne S, Haines R. The Contribution of psychologists to specialist palliative care. Int J Palliat Nurs. 2002; 8: 401-406.

10. Mariańczyk K, Steuden S. Oczekiwania oraz intencje zachowań zdrowotnych jako czynniki warunkujące wykonanie profilaktycznej cytologii w grupie kobiet po 45. roku życia. Psychoonkologia. 2011; 2: 55-64.

11. Majda A, Józefowska H. Zasoby osobiste pacjentów z przewlekłą obturacyjną chorobą płuc. Probl Piel. 2009; 17: 283-292.

12. Gapińska B. Poczucie własnej skuteczności a lęk i depresja u pacjentów po zabiegu wyłonienia stomii jelitowej. Współcz Onkol. 2008; 12: 84-89.

13. Paul-Kańska J. Choroba nowotworowa - w obliczu zagrożenia życia. Folia Psychologica. 2007; 11: 37-45.

14. Kofta M, Szustrowa T. Złudzenia, które pozwalają żyć. Warszawa: PWN; 2001.

Artykuł przyjęty do redakcji: 27.11.2015

Artykuł przyjęty do publikacj: 15.12.2015

Źródło finansowania: Praca nie jest finansowana z żadnego źródła. Konflikt interesów: Autorzy deklarują brak konfliktu interesów.

\author{
Adres do korespondencji: \\ Dorota Rogala \\ ul. Izabeli Romanowskiej 2 \\ 85-796 Bydgoszcz \\ tel.: 523743395 \\ e-mail:drogala@cm.umk.pl \\ Klinika Ginekologii Onkologicznej \\ Centrum Onkologii im. prof. Franciszka Łukaszczyka \\ w Bydgoszczy
}

